Brit. J. vener. Dis. (1964), 40, 3.

\title{
OCULAR SYNDROMES OF TRIC VIRUS INFECTION AND THEIR POSSIBLE GENITAL SIGNIFICANCE*
}

\author{
BY \\ BARRIE R. JONES \\ Department of Clinical Ophthalmology, Institute of Ophthalmology, University of London
}

As an ophthalmologist, I know that venereologists appreciate the great importance of applying specialized methods of examination, treatment, and follow-up to their clinical problems. In eye disease we have unique advantages in that so much is available, in life, for study by binocular microscopy under various conditions of perfect illumination, and that so much is readily accessible for cytological, histological, and microbiological investigation. Perhaps in no other field is the living tissue so accessible for microscopic study as it is in the conjunctiva and cornea. Furthermore, in the eye, the serious consequences of minute lesions demand this detailed study. I believe that certain methods we have used, and the experience we have gained, should be of value when applied to the genital mucosae and their affections.

I know that you physicians who have devoted yourselves to the study of sexually-acquired diseases practise the application of a broad background of general medicine to your patients' problems. It is the converging application of many pieces of highly detailed understanding derived from numerous fields, widely scattered in medicine, that is often rewarding. So I shall endeavour to give the background of some eye disease that is of interest to workers in both fields. For brevity and clarity, I shall have to be dogmatic and say some things that not all my ophthalmic colleagues would yet accept without a great deal of accompanying evidence. I shall explain and illustrate what is meant by trachoma and by inclusion blennorrhoea, as it presents in its various syndromes: neonatal inclusion blennorrhoea, adult or swimming-bath inclusion conjunctivitis, inclusion cervicitis, and inclusion urethritis, and shall discuss certain aspects of their inter-relations and their associations with the genital tract. This will lead to the new (TRIC virus) nomenclature for

\footnotetext{
* Paper read to the M.S.S.V.D. in London on March 29, 1963.
}

isolates of virus from all these conditions, and the promising lines of investigation that lie ahead.

\section{Trachoma}

Trachoma appears to have been one of the first afflictions of man to be recognized as a clinical entity. It is mentioned in the Ebers papyrus of 1500 B.C., and is known to have been widespread in ancient Egypt, Greece, and Rome. The name, meaning "rough eye", was given in A.D. 60 and the four stages of the condition were delineated by Galen (Thygeson, 1962). It appears to have been spread from the Middle East to Europe by the returning Crusaders, and again by Napoleon's army returning from Egypt. Hence the term "military ophthalmia". During the 19th century it has gradually disappeared from Northern Europe but has persisted in the Mediterranean countries, the Middle and Far East, Africa, and certain areas of South America. In North America it is largely confined to Mexico and the American Indians. It probably still afflicts about one-seventh of the world's population.

Trachoma has been defined in the Third Report of the WHO Expert Committee on Trachoma (WHO, 1962) as "a specific communicable kerato-conjunctivitis, usually of chronic evolution, caused by an agent belonging to the psittacosis-lymphogranulomatrachoma (PLT) group of atypical viruses, and characterized by follicles, papillary hyperplasia, pannus, and, in its later stages, cicatrization. The clinical diagnosis of trachoma requires the presence of at least two of the following signs:

(1) Follicles on the upper tarsal conjunctiva, limbal follicles or their sequelae (Herbert's pits);

(2) Epithelial or subepithelial keratitis, most marked in the upper third of the cornea;

(3) Pannus, most marked superiorly;

(4) Characteristic conjunctival scarring. 
In the earliest stage of infection the eye presents the signs of an acute or subacute conjunctivitis with diffuse hyperaemia, oedema, and infiltration of the conjunctiva (Fig. 1).
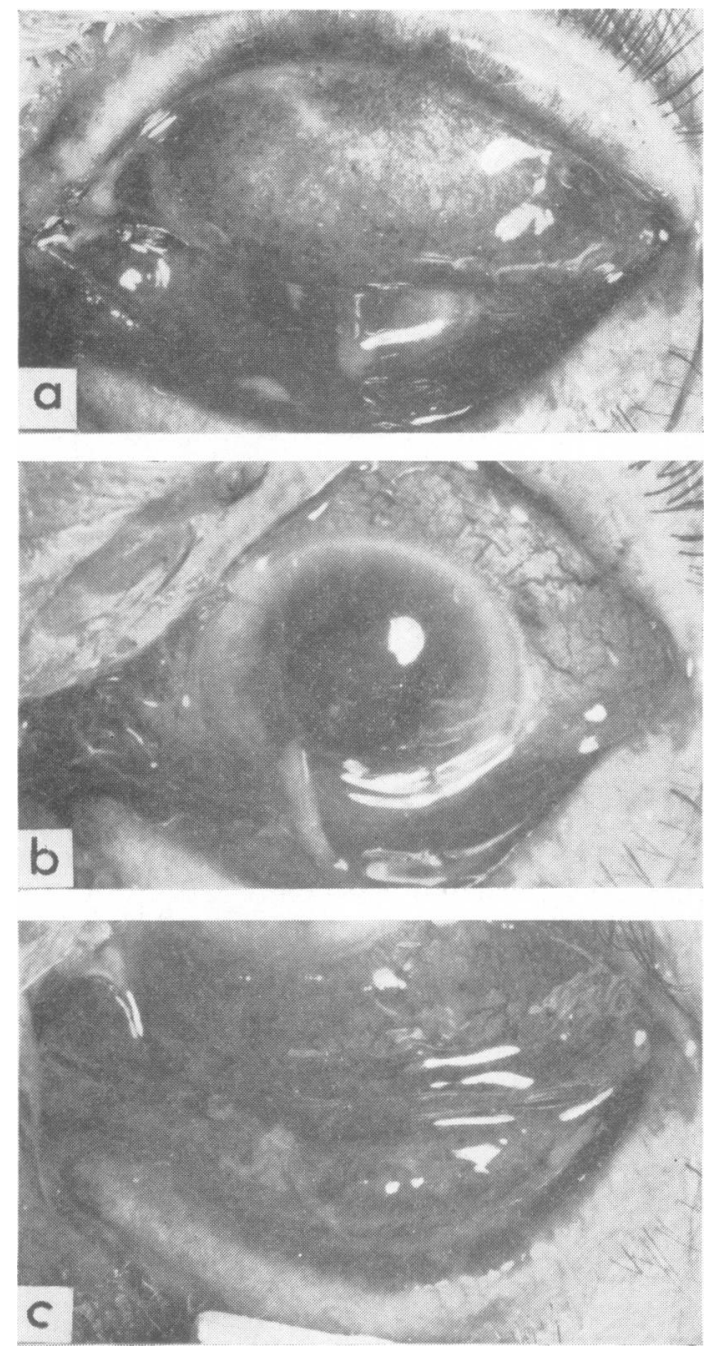

FIG 1.-TRACHOMA STAGE DUBIUM ( $\operatorname{Tr} D)$. Eye of volunteer 2 days after inoculation of virus, showing acute muco-purulent conjunctivitis.

(a) Oedema, hyperaemia, and commencing infiltration of conjunctiva of upper lid.

(b) Congestion and oedema of bulbar conjunctiva.

(c) Severe oedema, hyperaemia, and infiltration of conjunctiva of lower fornix and lid.

There is a variable amount of muco-purulent discharge; enlargement of the vascular papillae on the tarsal conjunctiva gives a fine mosaic-like appearance. The corneal epithelium is often diffusely roughened and swollen; there is congestion of the vessels at the limbus. Because the condition cannot be differentiated clinically from other forms of conjunctivitis, this stage is often referred to as Trachoma dubium (Tr D) in surveys based on clinical assessment without laboratory studies. It is, however, the earliest stage of infection by the causal agent of trachoma.

Then follow four clinically recognizable stages:

In Trachoma Stage I $(\operatorname{Tr} I)$ relatively avascular cellular foci of lymphoid hyperplasia appear amidst the increasing papillary hypertrophy of the upper tarsal conjunctiva (Fig. $2 a, c$, opposite). Follicles appear first in the lower and upper fornices and in the lower lid, but it is only when they appear on the upper tarsal area that the diagnostic picture of trachoma emerges. The diffuse and punctate keratitis develops and leads to microscopic pannus from invasion of the cornea by newly formed capillary loops (Fig. $2 b$ ) (Thygeson 1962).

The infection thus passes through an acute phase ( $\operatorname{Tr} D)$ and a subacute phase ( $\operatorname{Tr} I)$ into a chronic stage, Trachoma Stage II (Tr II). In this stage the conjunctiva is more solidly infiltrated and swollen from papillary hypertrophy but is rather less hyperaemic and oedematous (Fig. $3 a, b, c$, opposite). The tarsal follicles become swollen and soft like cooked sago. These necrotic follicles are easily ruptured. Corneal infiltration continues and usually the pannus increases but becomes less congested with the passage of time. When the small linear or stellate scars first appear they tend to be obscured by the florid papillary hypertrophy with soft necrotic follicles (Fig. $4 a, c$, overleaf, p. 6). As healing progresses, however, scarring increases and the papillae and follicles diminish (Fig. $5 a, c$, overleaf, p. 6).

The onset of healing is marked by the appearance of scarring in the conjunctiva. Trachoma Stage III ( $\operatorname{Tr}$ III) is thus characterized by the signs present in Stage II with the addition of scarring (Fig. 4). As time goes by, the scars increase and the signs of activity diminish.

Trachoma Stage IV ( $\mathrm{Tr}$ IV) is the stage of healed trachoma, in which the follicles and enlarged papillae of the earlier stages have disappeared (Fig. 6, overleaf, p. 7). The limbal follicles have vanished, leaving clear depressions in the opacified limbus, known as Herbert's pits. The pannus becomes attenuated and active infiltration of the cornea disappears. The disease is no longer infective but the cicatrization may lead to increasing distortion of the lids and progressive corneal blindness. 

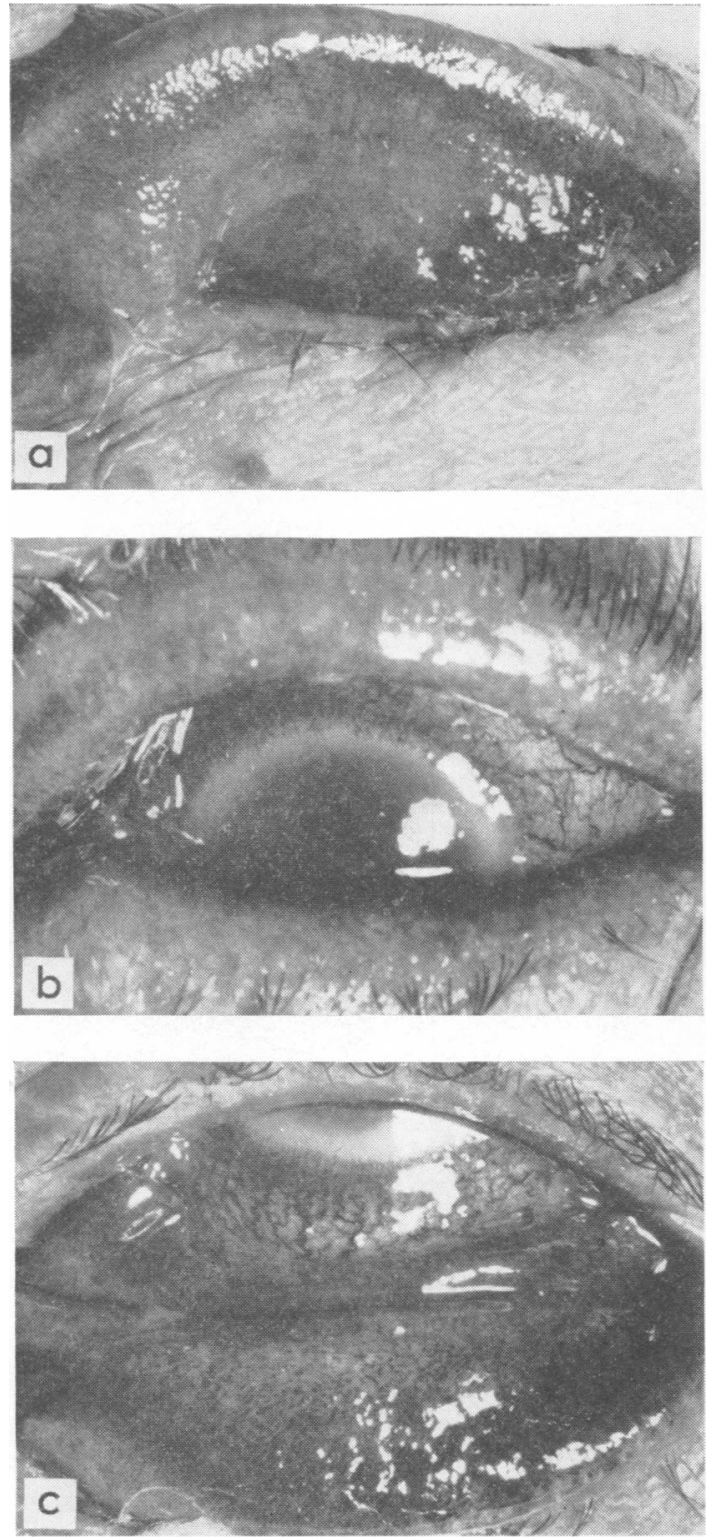

Fig. 2.-TRACHOMA STAGE I (Tr I). Eye of volunteer 24 days after inoculation of virus, showing severe subacute conjunctivitis with less muco-pus than Fig. 1.

(a) Papillary hypertrophy and tiny follicles just appearing in upper lid.

(b) Typical micro-pannus, i.e. vessels growing into infiltrated peripheral cornea.

(c) Less marked extension of vessels into cornea is occurring at lower limbus, with papillary hypertrophy in lower lid and a few follicles just appearing.
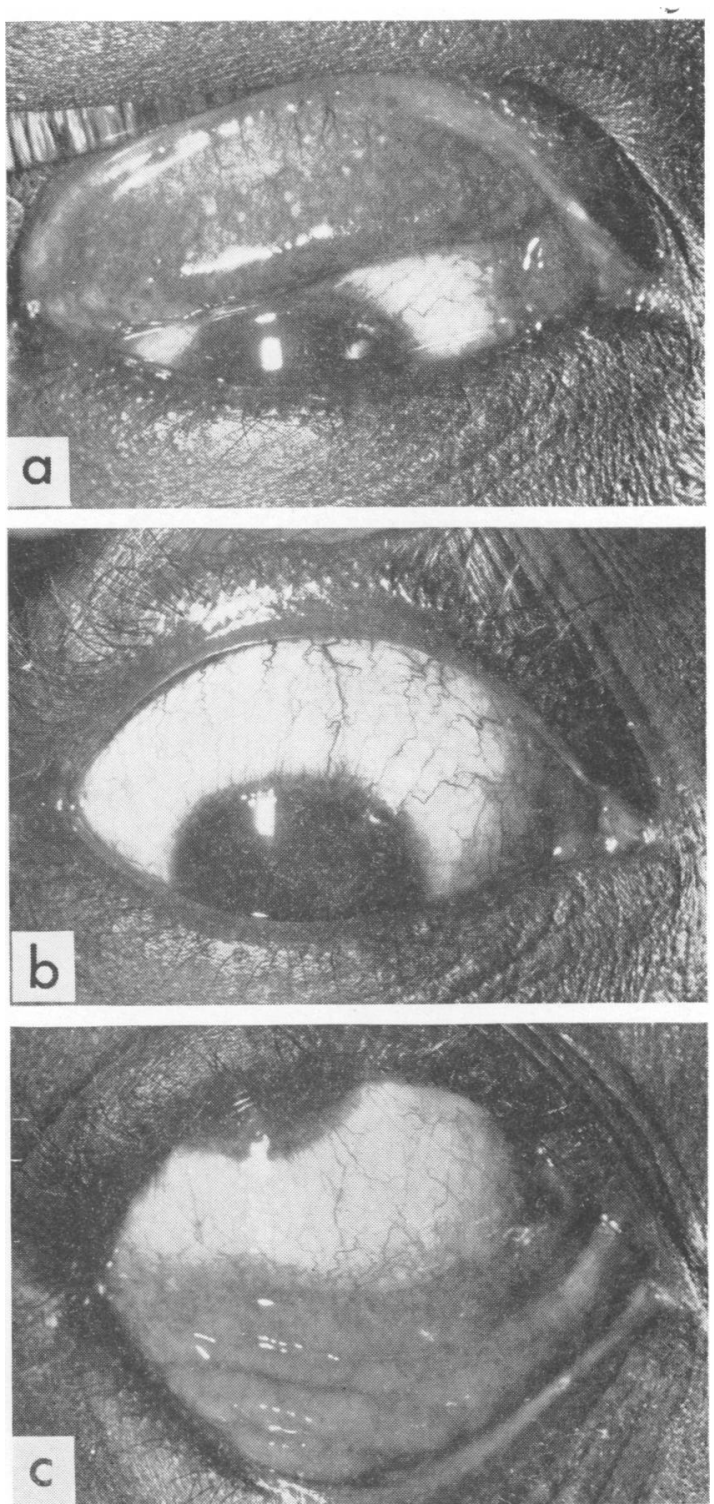

FIG. 3.-TRACHOMA STAGE II (Tr II). Early stage II trachoma in a West Indian woman.

(a) Soft necrotic follicles amid fine papillary hypertrophy of tarsal conjunctiva.

(b) Limbal follicles present, but difficult to see in this photograph.

(c) Follicles in lower fornix. 


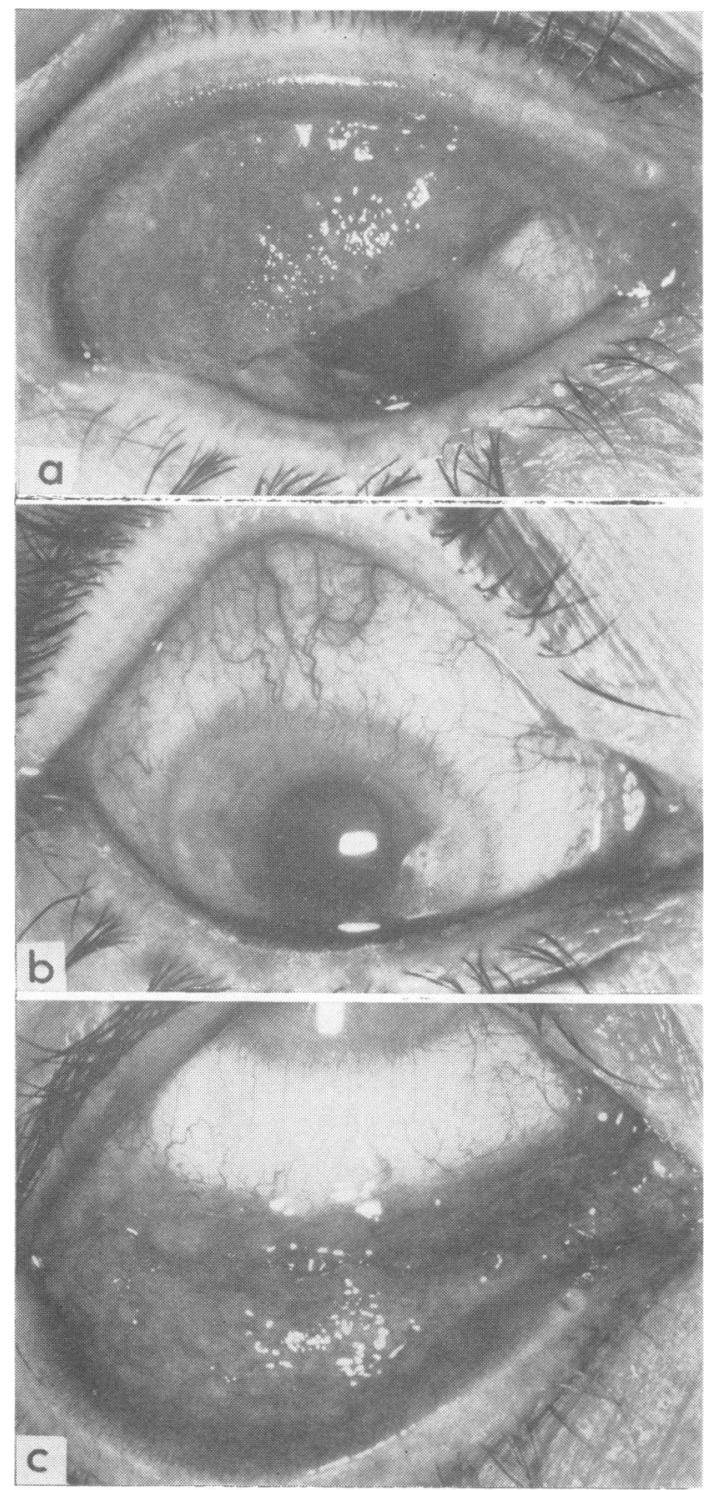

FIG. 4.-TRACHOMA STAGE III (Tr III). Early stage III trachoma in an English woman on March 21, 1960. (See also Figs 5 and 17.)

(a) Linear and stellate scars appearing in tarsal conjunctiva (especially in subtarsal groove), necrotic follicles, and gross papillary hypertrophy in upper lid.

(b) Pannus.

(c) Follicles in lower fornix and lid and around caruncle.
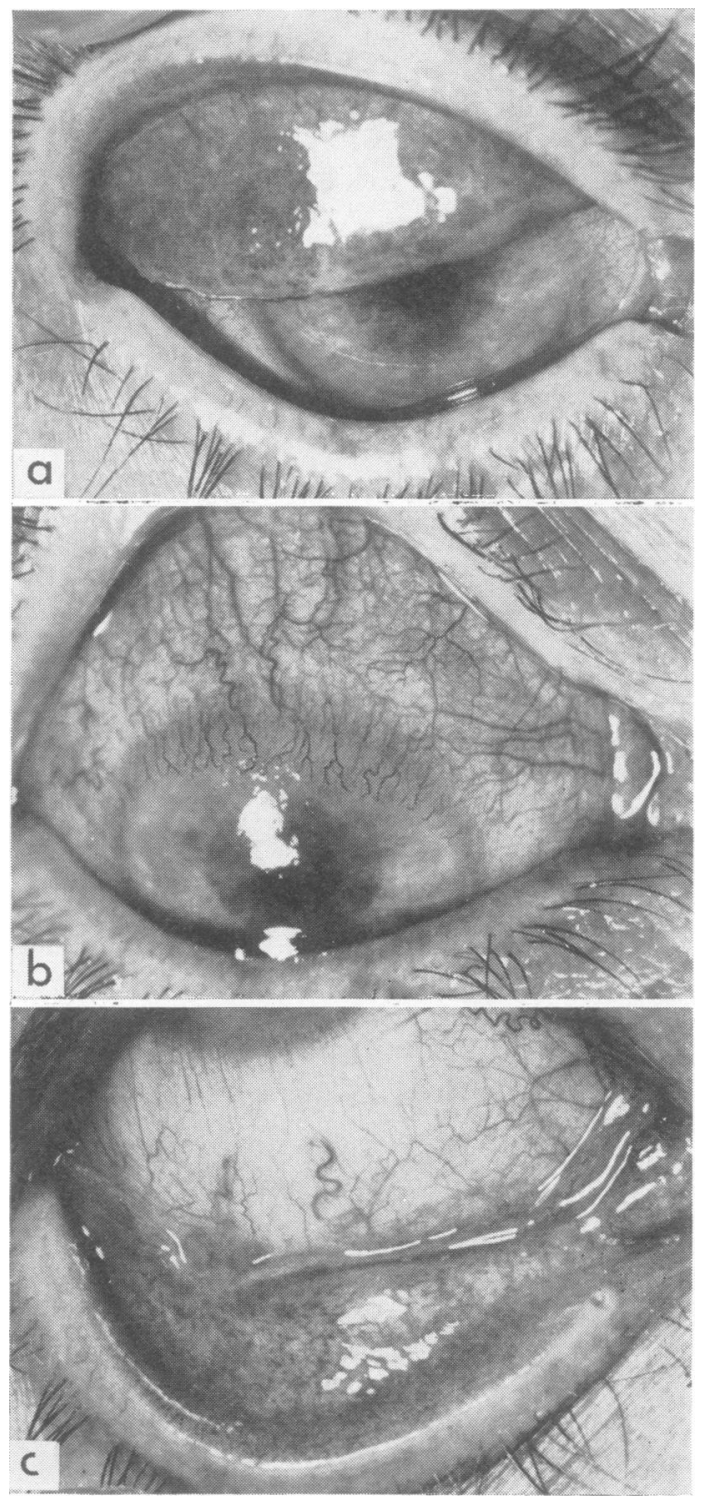

FIG. 5.-TRACHOMA STAGE III (Tr III). Late trachoma stage III, in the same patient as in Figs 4 and 17, on April 19, 1961.

(a) Increased scarring, some typical stellate scars visible; fewer follicles and papillae smaller than in Fig. $4(a)$.

(b) Progression of pannus.

(c) Many fewer follicles than in Fig. 4 (c); small stellate cicatrices in lower lid. 

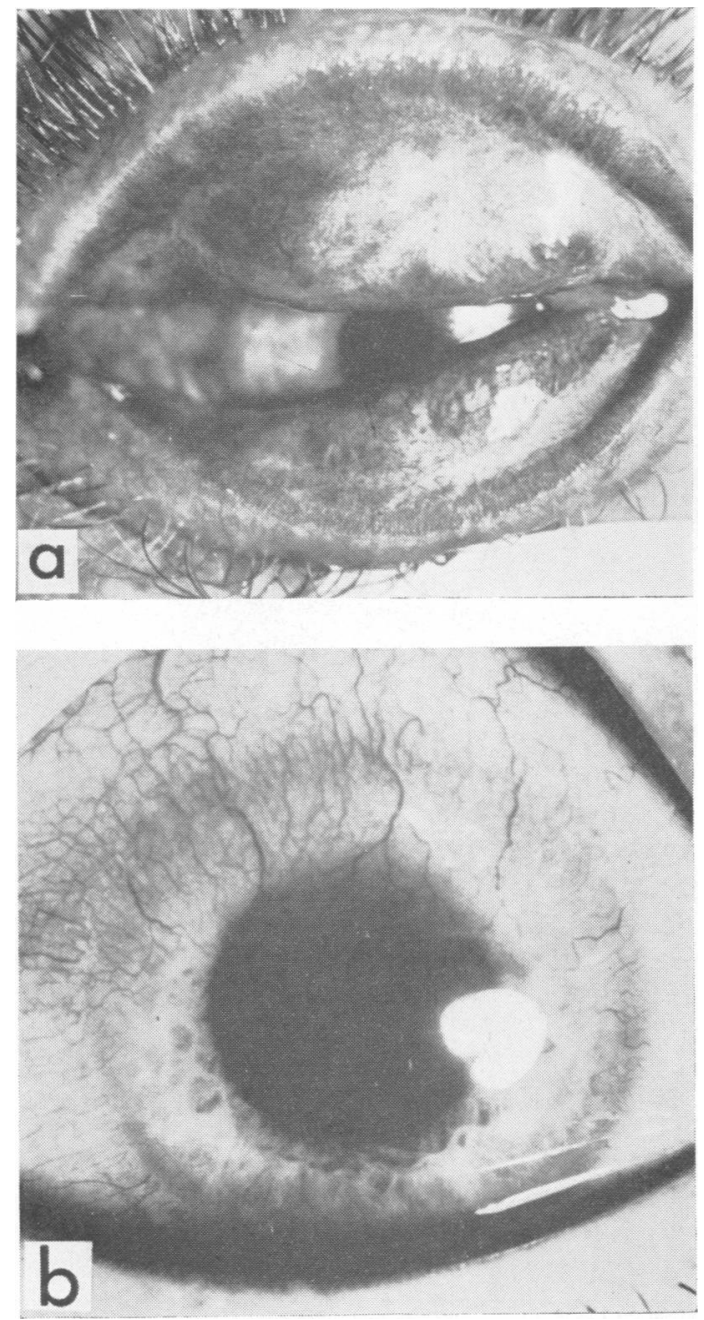

To clarify the arguments of the last 50 years, intensified by our own work during the last 5 , about the relationship of trachoma and inclusion blennorrhoea, it is both logical and very valuable to employ the word "trachoma" in the sense in which it has been used since earliest times, that is to say, simply as the term for this rather clear-cut clinical syndrome of eye disease. This leaves us uncommitted, whether the causal agent of trachoma may sometimes give rise to other syndromes of ocular or genital infection, or whether related agents, usually causing different ocular or genital syndromes, may occasionally give rise to the trachoma syndrome.

The aetiology of trachoma began to be unravelled when Halberstaedter and von Prowazek (1907), who were investigating syphilis in Java, turned their

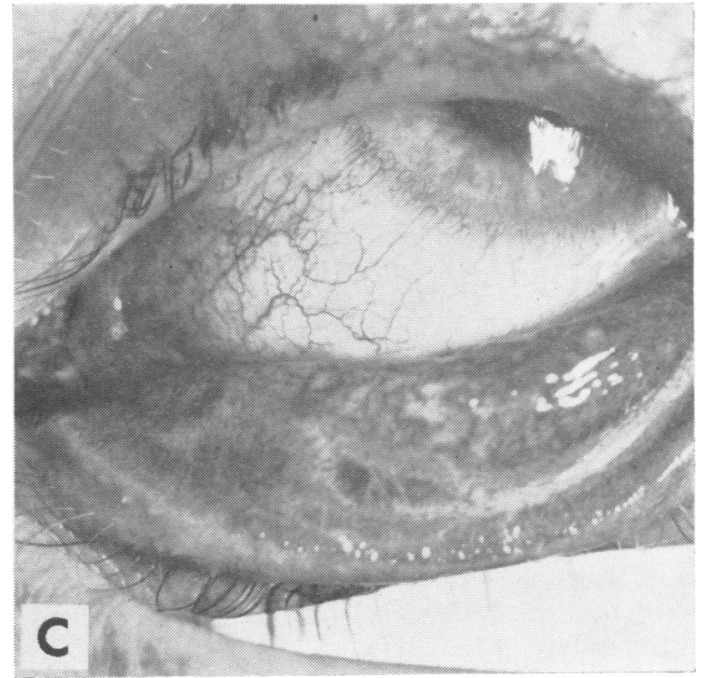

Fig. 6.-TRACHOMA STAGE IV (Tr IV).

(a) Scarring in upper tarsal conjunctiva.

(b) Inactive pannus.

(c) Scarring in lower lid, especially in subtarsal groove.

attention to trachoma. They transmitted the disease to the eyes of orang-outangs. In the scrapings from the conjunctiva of these animals they found the cytoplasmic inclusion bodies that bear their names. Subsequent work (Lindner, 1910a; Rice, 1936; Thygeson, 1938) has shown that there is a life cycle which commences with the entry of a single small eosinophil elementary body into the cell. This swells and becomes a basophil initial body which appears to divide to produce smaller basophil bodies, and subsequently gives rise to an inclusion body consisting of mixed basophil and eosinophil particles. Eventually a large inclusion body is formed of small eosinophil elementary bodies embedded in a matrix which contains glycogen. The cell ruptures to liberate free elementary bodies. This life cycle, which was worked out by Thygeson, closely resembles those of other members of the Psittacosis-lymphogranuloma (PLT) group of atypical viruses, or Bedsonia.

T'ang, Chang, Huang, and Wang (1957) isolated virus from trachoma by serial cultivation in the yolk sacs of embryonated hen eggs. This was confirmed by Collier and Sowa (1958) in West Africa. They showed that the agent contained the group antigen and appeared the same on electron-microscopic examination as other members of the PLT group. Collier, Duke-Elder, and Jones (1958) established that this cultivated virus could reproduce the disease in man and these observations have now been confirmed in several countries. 
All this seems rather straightforward ophthalmology and you may be wondering what genital significance it may have.

\section{INCLUSION BLENNORRHOEA}

Very soon after Halberstaedter and von Prowazek's discovery, Stargardt (1909) found similar inclusions in bacteria-free ophthalmia neonatorum. Lindner (1909b) introduced the term inclusion blennorrhoea for the disease (Fig. 7).

Halberstaedter and von Prowazek (1910) found inclusions in scrapings of the cervix of nothers of babies with inclusion blennorrhoea and Lindner $(1910 \mathrm{a}, \mathrm{b})$ found them in the urethra in three cases of non-gonococcal urethritis. Fritsch, Hofstatter, and Lindner (1910) infected monkeys' eyes with material from this type of urethritis, with material from the mothers' genital disease, and also from the disease in the infant.
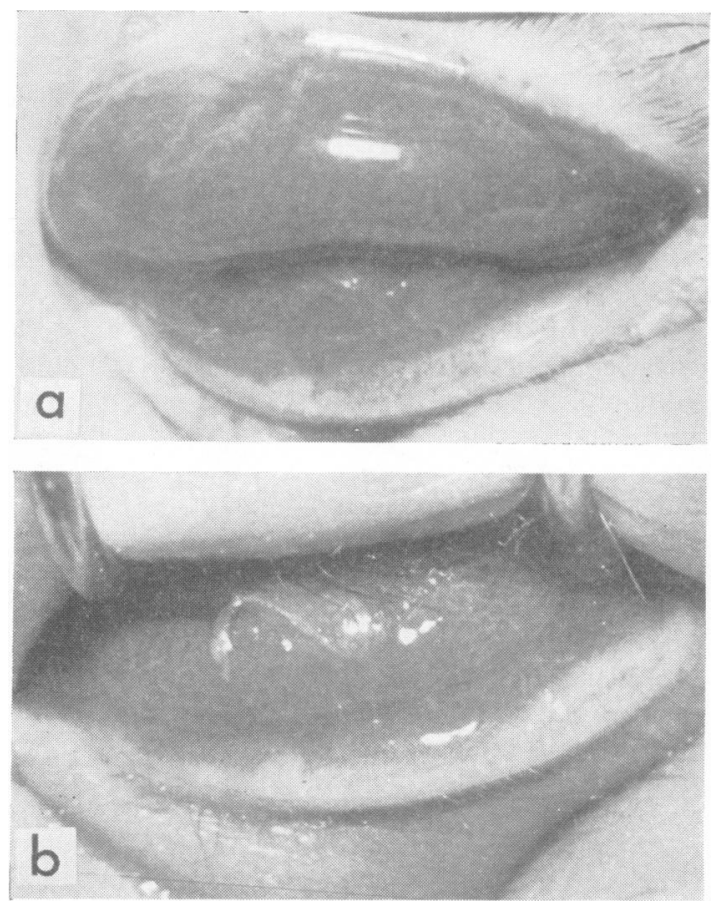

FIG. 7.-INCLUSION BLENNORRHOEA OF THE NEWBORN.

(a) Acute papillary conjunctivitis of both upper and lower lids.

(b) Muco-purulent discharge, oedema, and papillary hypertrophy in lower lid and fornix.

Thus inclusion blennorrhoea was shown to be a disease of the neonatal eye and of the genital tract in both male and female. It was regarded at first as a genital form of trachoma, but this view has been discarded and it has come to be regarded as the genital and neonatal form of swimming-bath conjunctivitis, or inclusion conjunctivitis of the adult.

The neonatal inclusion blennorrhoea is an acute papillary muco-purulent conjunctivitis (Fig. 7) that runs a benign self-limiting course for weeks or months, to heal without pannus or scarring.

\section{INCLUSION CONJUNCTIVITIS}

Inclusion conjunctivitis of the adult is a chronic follicular conjunctivitis, of acute or subacute onset,
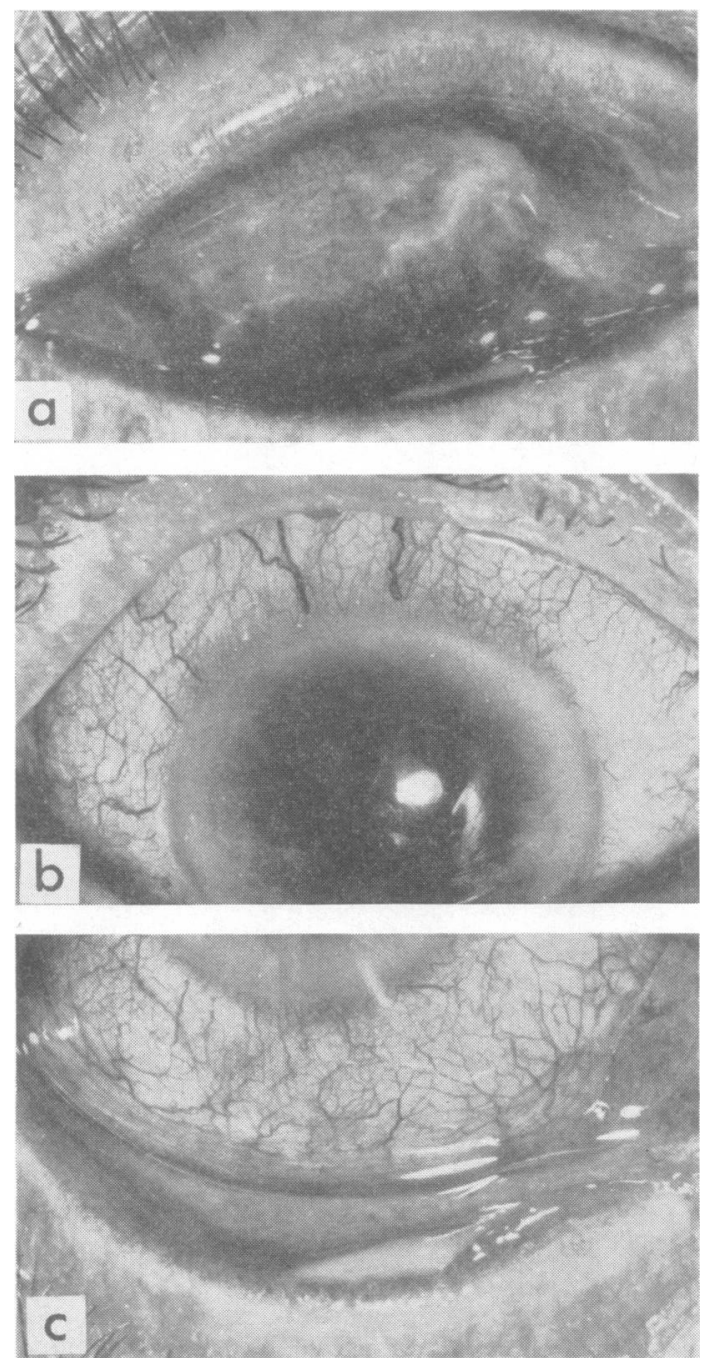

FIG. 8.-INCLUSION CONJUNCTIVITIS, STAGE DUBIUM (IC D). Eye of volunteer one day after inoculation of virus, showing acute muco-purulent conjunctivitis.
(a) Oedema and hyperaemia of tarsal conjunctiva with muco-
purulent discharge.
(b) Hyperaemia of globe.
(c) Hyperaemia and oedema of lower lid and fornix with muco- purulent discharge. 
characterized by a follicular inflammation most marked in the lower fornix and lower lid but also extending to the region of the plica, caruncle, and upper fornix. The cornea remains unaffected, and after a period of months the disease resolves without conjunctival scarring, and without pannus or other corneal abnormality.

In order to facilitate an understanding of the condition and its differential diagnosis, I should like to divide it, as is done with trachoma, into four clinically recognizable stages preceded by one that cannot be identified without laboratory aids. In this earliest stage of infection, which I would call Inclusion Conjunctivitis Dubium (IC D), the eye presents signs of acute or subacute conjunctivitis with diffuse hyperaemia, oedema, and infiltration of the conjunctiva (Fig. 8, p. 8). There is a variable muco-purulent discharge. Although the cornea is not involved, the vessels at the limbus are commonly congested and the condition cannot be differentiated
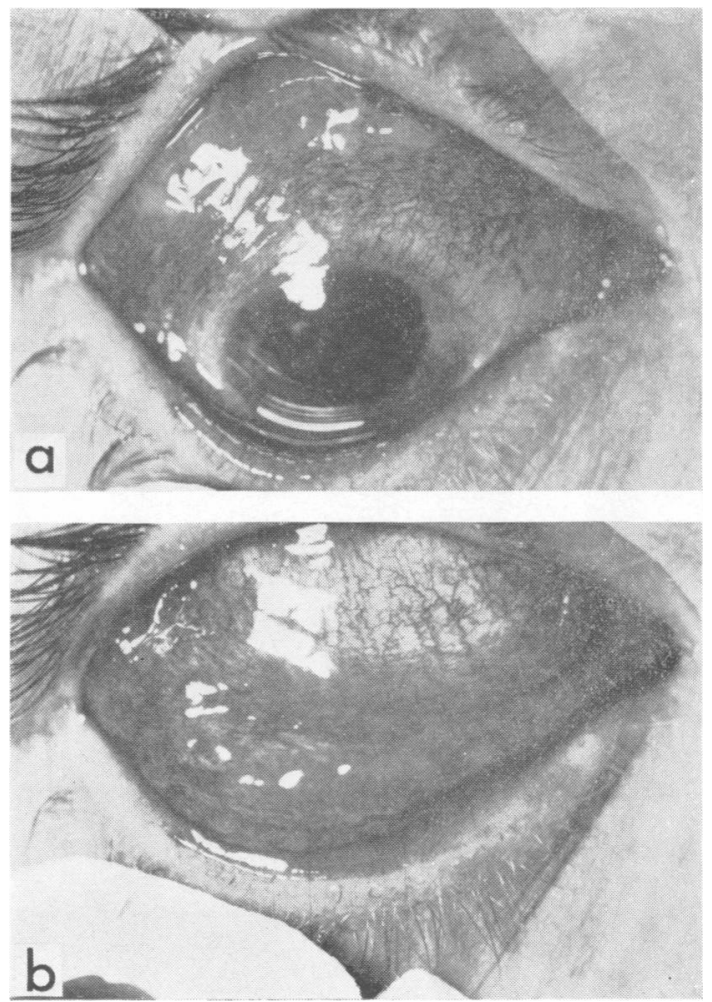

Fig. 9.-INCLUSION CONJUNCTIVITIS STAGE I (IC I). Severe follicular conjunctivitis of 4 weeks' duration with muco-purulent discharge.

(a) Oedema, hyperaemia, and some infiltration of conjunctiva congestion of limbal vessels but no extension on to cornea.

(b) Early follicular reaction maximum in lower fornix. from the dubium stage of trachoma nor, on clinical grounds, from bacterial conjunctivitis.

Then follow four typical stages. If we preserve the analogy with the recognized stages of trachoma, the next stage should be called Inclusion Conjunctivitis Stage I (IC I). It can commonly be recognized about 4 weeks after the onset (Fig. 9). Follicles appear first and most markedly in the lower fornix and lower lid but also to some extent in the upper fornix, in the plica, and around the caruncle. The relative absence of follicles on the upper tarsus and the absence of both keratitis and pannus serve to distinguish it from Tr I (see Fig. 2).

Thus, after an acute phase (IC D) and a subacute phase (IC I), the condition passes into a chronic phase Inclusion Conjunctivitis Stage II (IC II). In this stage the conjunctiva is more solidly infiltrated and follicular but is less hyperaemic and oedematous than in IC I (Fig. 10). Follicles are most numerous
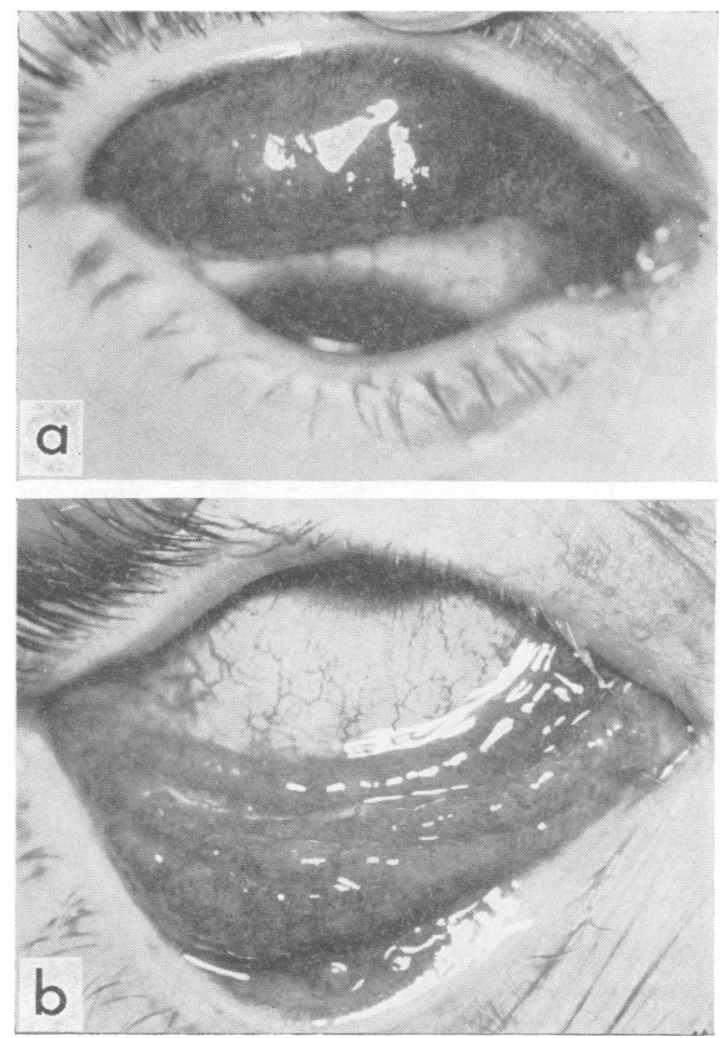

Fig. 10.--INCLUSION CONJUNCTIVITIS STAGE II (IC II). Follicular conjunctivitis of 12 weeks' duration.

(a) Some thickening of upper tarsal conjunctiva; follicles in upper fornix.

(b) Solid follicular reaction in lower fornix, lid plica, and region of caruncle, some flecks of muco-pus between follicles. 
in the lower fornix and lid. The absence of soft necrotic follicles on the upper tarsal plate and the absence of both keratitis and pannus distinguish it from Tr II (see Fig. 3).

The onset of healing in Inclusion Conjunctivitis Stage III (IC III) is indicated by progressive loss of signs of activity, notably hyperaemia (Fig. 11). The globe itself is white and the follicles gradually become
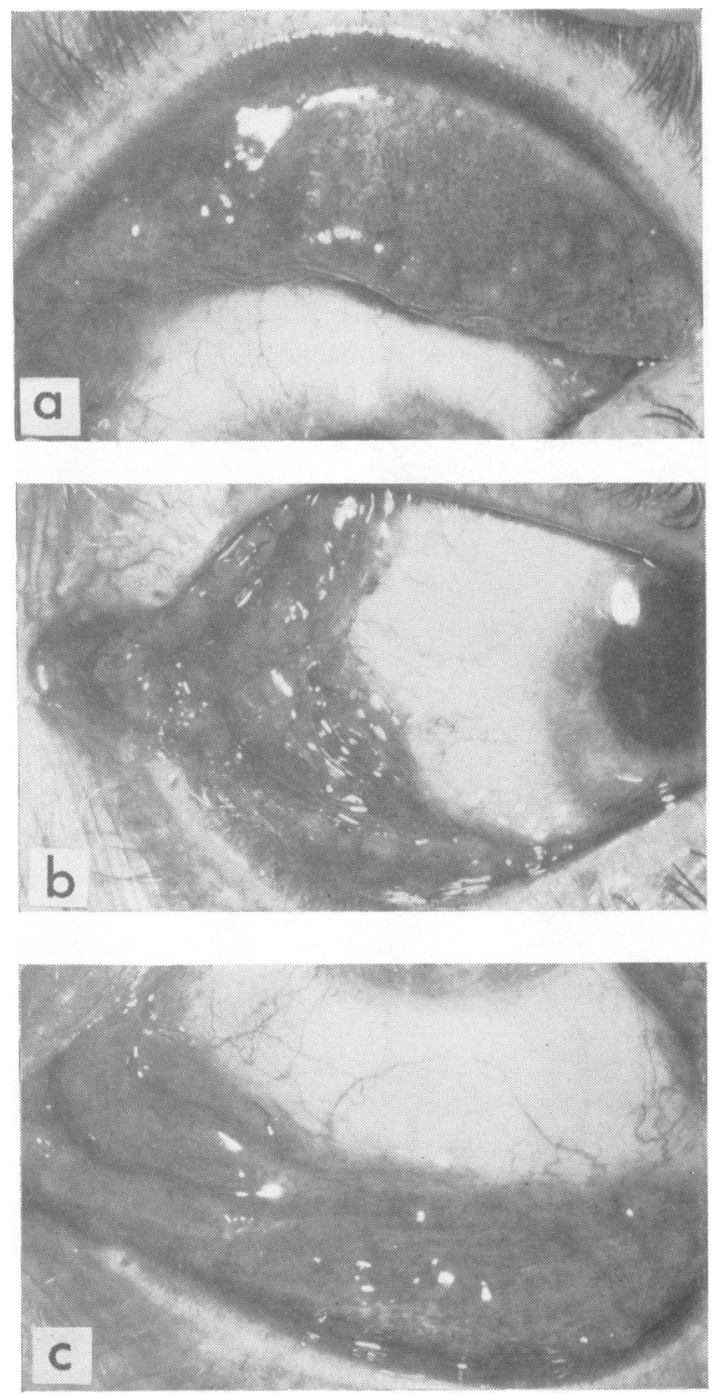

FIG. 11--INCLUSION CONJUNCTIVITIS STAGE III (IC III). Follicular conjunctivitis of one year's duration.

(a) Upper lid showing follicles, mainly at border of tarsal plate; no soft necrotic follicles.

(b) Cornea not involved; many large follicles in plica and around caruncle.

(c) Follicles in lower fornix but diffuse infiltration between follicles less marked than in Fig. $10(b)$. less florid. The diffuse infiltration between the follicles disappears, so that IC III could be confused with folliculosis.

Unlike $\operatorname{Tr}$ III, there is no fibrosis around the follicles, which do not become necrotic, and no scarring occurs in the conjunctiva (see Figs 4 and 5). The cornea remains uninvolved.

The process of healing proceeds gradually to complete resolution without any trace of scarring or pannus, so that in Inclusion Conjunctivitis Stage IV (IC IV) there is a return to clinical normality (Fig. 12).
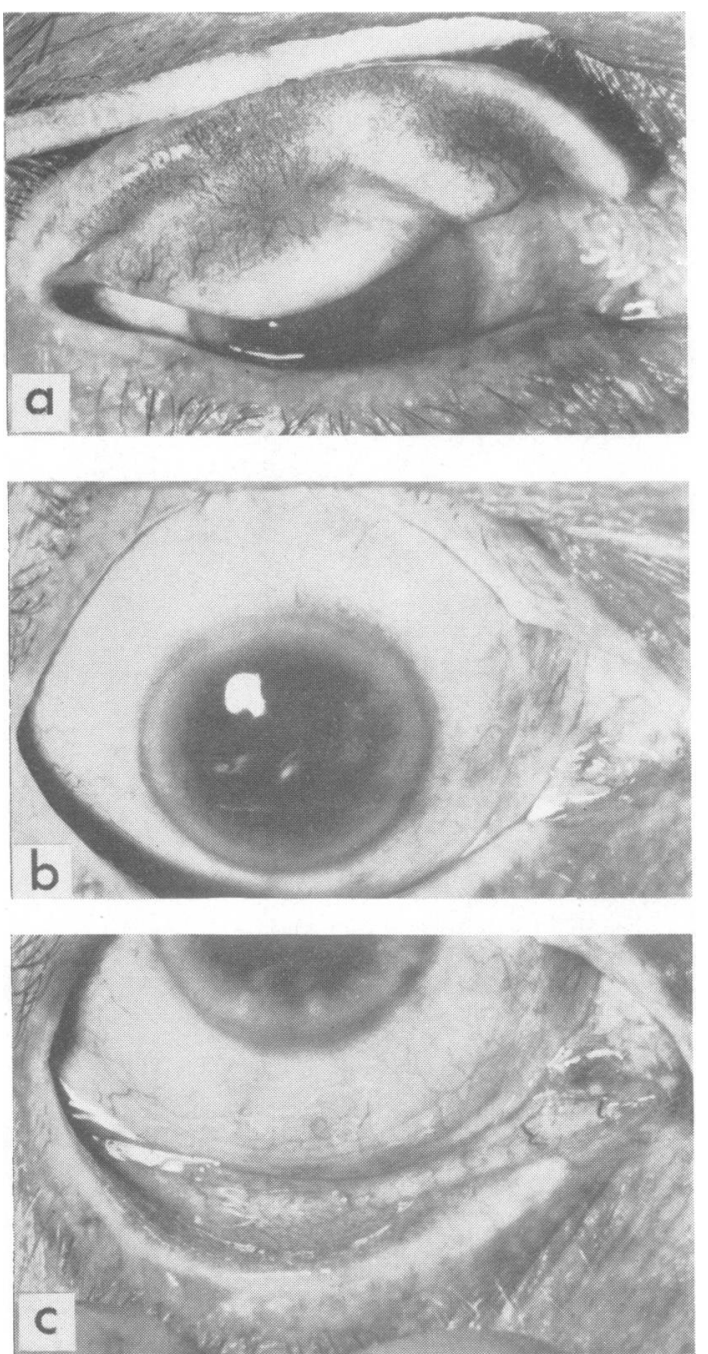

Fig. 12.-INCLUSION CONJUNCTIVITIS STAGE IV (IC IV). Experimental inclusion conjunctivitis in volunteer's eye-completely resolved, one year after inoculation.
(a) Upper lid.
(b) Cornea.
(c) Lower lid. 
The features that differentiate inclusion conjunctivitis from trachoma are, thus, that the former is a more acute, self-limiting condition in which the maximum disease is seen in the lower rather than the upper lid, and that it heals without scarring or affecting the cornea.

On the basis of this differentiation, and the fact that inclusion blennorrhoea is not recognized in areas where trachoma is widespread, two causal agents were postulated and named Chlamydia trachomatis and Chlamydia oculogenitale respectively, long before they were isolated.

\section{Tric Virus Punctate Kerato-conjunctivitis}

In a careful study of 47 inclusion-positive cases in London, fourteen were neonatal infections; of 29 adult cases I was able to classify seven as typical inclusion conjunctivitis, eight as typical trachoma, five as atypical trachoma, and eight as typical of an intermediate clinical sy'ndrome that I called "TRIC virus punctate kerato-conjunctivitis".

This syndrome of TRIC virus punctate keratoconjunctivitis resembles inclusion conjunctivitis but includes signs of punctate keratitis otherwise seen only in the trachoma sy'ndrome (Jones, 1961).

Although the conjunctivitis begins acutely or subacutely with some muco-purulent discharge and passes through the stages of inclusion conjunctivitis without having soft necrotic follicles or conjunctival

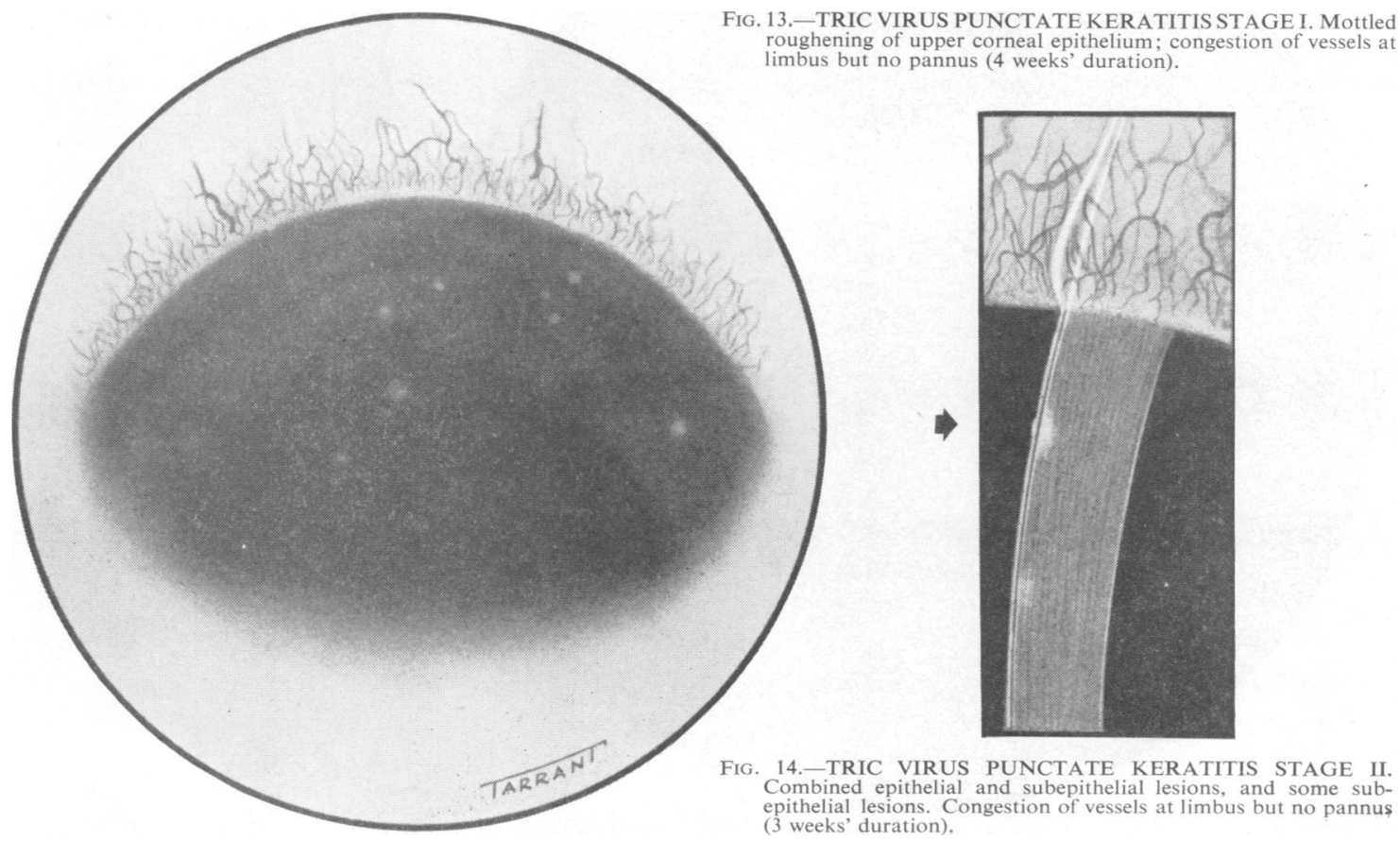

scarring, the patients are considerably disturbed by a persistent punctate keratitis, which differentiates the condition from inclusion conjunctivitis. This keratitis begins with a diffuse, mottled roughening and opacification of the corneal epithelium (Fig. 13); more pronounced epithelial opacifications with swelling then occur and these rapidly lead to buffcoloured subepithelial infiltrations which persist for a number of months after the epithelial disease has healed (Fig. 14).

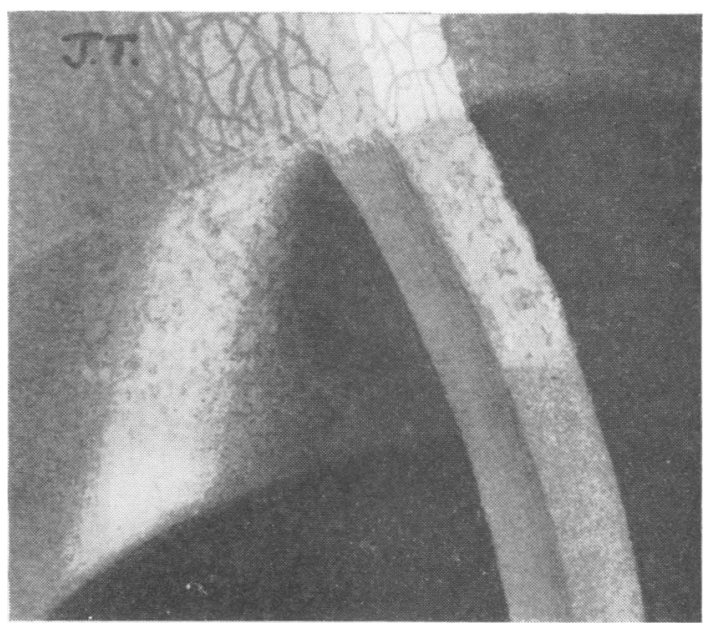

IG. 13.-TRIC VIRUS PUNCTATE KERATITIS STA GE I. Mottled roughening of upper corneal epithelium; congestion of vessels at ( 3 weeks' duration), 
During this time the subepithelial opacities gradually become less yellowish and more greyishwhite in colour and less swollen in appearance. Successive crops of lesions may develop over a period of many months up to a year or so (Fig. 15). Lesions of this type occur in trachoma and this would be the diagnosis if pannus or scarring of the conjunctiva occurred. But, in the absence of scarring and pannus, the disease cannot be called trachoma, and virus isolated from this condition (Dr. Collier's isolate TRIC/ GB/MRC-5/0 illustrated in Fig. 15) cannot be designated as either "trachoma virus" or "inclusion conjunctivitis virus".

In my opinion, therefore, the clinical differential diagnosis of trachoma and inclusion conjunctivitis is not always sufficiently clear-cut to serve as the sole basis of naming two causal organisms. It was for this reason that in 1959, when we isolated virus from a baby with neonatal inclusion blennorrhoea (isolate LB 2, redesignated TRIC/ /GB/MRC-2/ON) and from the cervix of the mother of such a baby (isolate LB 1, redesignated TRIC/ /GB/MRC-1/G), we did not claim to have isolated Chlamydia oculogenitale (Jones, Collier, and Smith, 1959). Similar

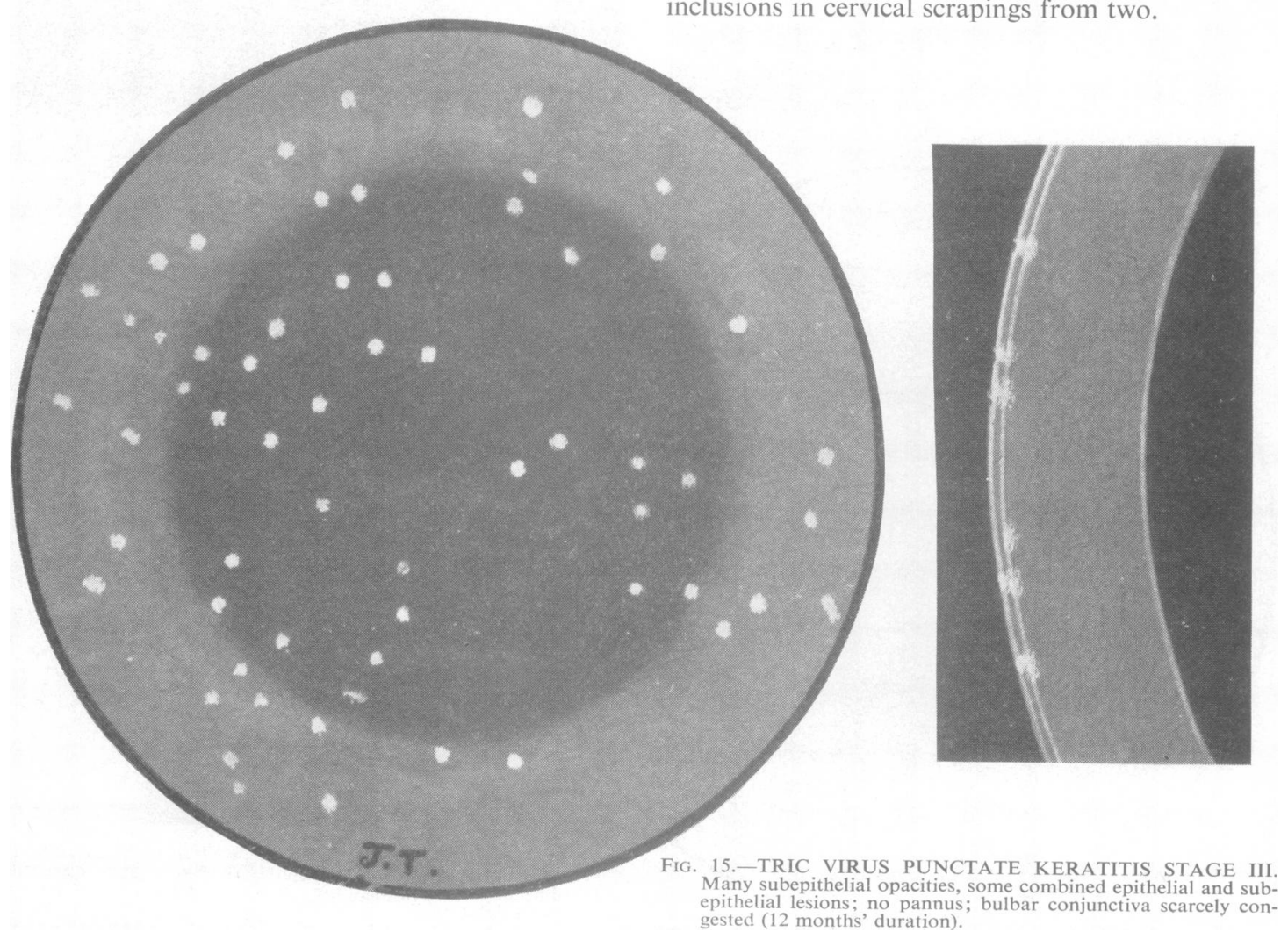

isolations from the neonatal disease have been made in California (Hanna, Zichosch, Jawetz, Vaughan, and Thygeson, 1960), but in the laboratory no one has yet discovered any way of distinguishing these from virus isolated from trachoma.

If my 47 cases are arranged according to age and sexual activity, an interesting pattern emerges (Fig. 16 , opposite). There is a group of fourteen neonates whose eyes have become infected during passage through the birth canal. Then there is a group of 21 patients whose eyes (and probably their genital tract also) have become infected during their initial sexual experiences at 19 to 27 years of age. Although only seven of the 21 patients in this group are married, all except two of the others had engaged in sexual activities within a few weeks preceding the onset of eye symptoms. In the six persons in the next age group, 35 to 52 , it is likely that subsequent sexual contacts were making their effects felt. Of the two men in this group, one was a promiscuous homosexual and the other was indulging in extra-marital relations. Of the four women, all had been married a number of years, all had cervicitis, and I found inclusions in cervical scrapings from two. 


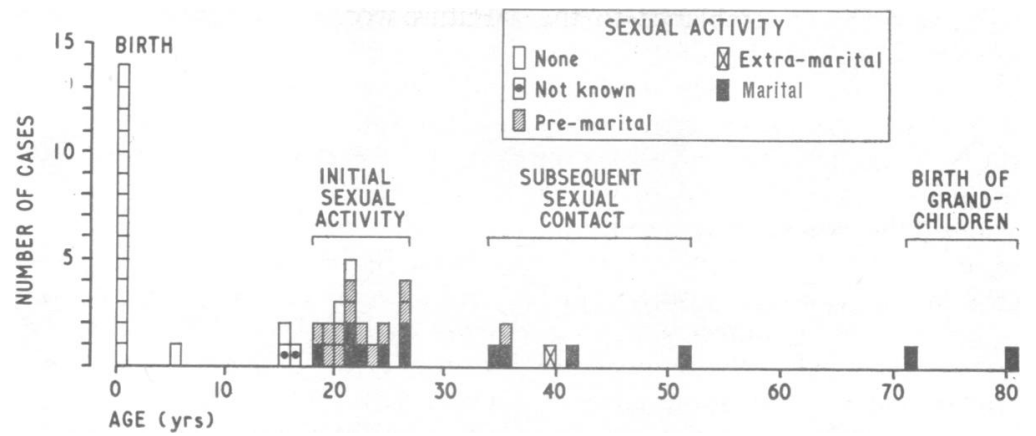

FIG. 16.-Age incidence of TRIC virus infections in London and the relation of sexual activity to these infections.

There were two aged patients, no longer sexually active; both were living with their children and had been closely associated with a grandchild born with ophthalmia neonatorum.

This takes us back to birth and leaves four patients. One aged 5 and another aged 16 gave the duration of their symptoms as "all their lives", and the latter was known to have had ophthalmia neonatorum. The first isolation of trachoma virus in Britain (isolate LT1, redesignated TRIC/ /GB/MRC-01/OT) was made in 1957 from this child's Stage III trachoma.

Since both inclusion conjunctivitis and trachoma appeared to be associated with exposure to sexuallytransmitted infection, I began to examine the genital tract of patients presenting with either syndrome. Of three men presenting with acute trachoma following sexual exposure, all had asymptomatic urethritis on the basis of the two-glass test, and in all three the cytological findings in urethral scrapings resembled those seen in trachoma, although no inclusions were found. Of seven women investigated, cervicitis appeared to be present in six and inclusions were found in cervical scrapings from two, one of whom had inclusion conjunctivitis and the other trachoma.

When this last woman was referred to me for investigation she presented a typical though unilateral Stage III trachoma (Fig. 4), and from this eye virus was isolated (isolate LT2, redesignated TRIC/ /GB/MRC-02/OT). The ocular symptoms extended over 2 years from the date when she had consulted her doctor about her vaginal discharge. This failed to resolve after cautery of papillomata and the use of pessaries. She had urethritis with a pouting, inflamed urethral meatus and granular cervicitis with a muco-purulent discharge (Fig. 17a, $b$ ). The granules on the cervix in the vicinity of the
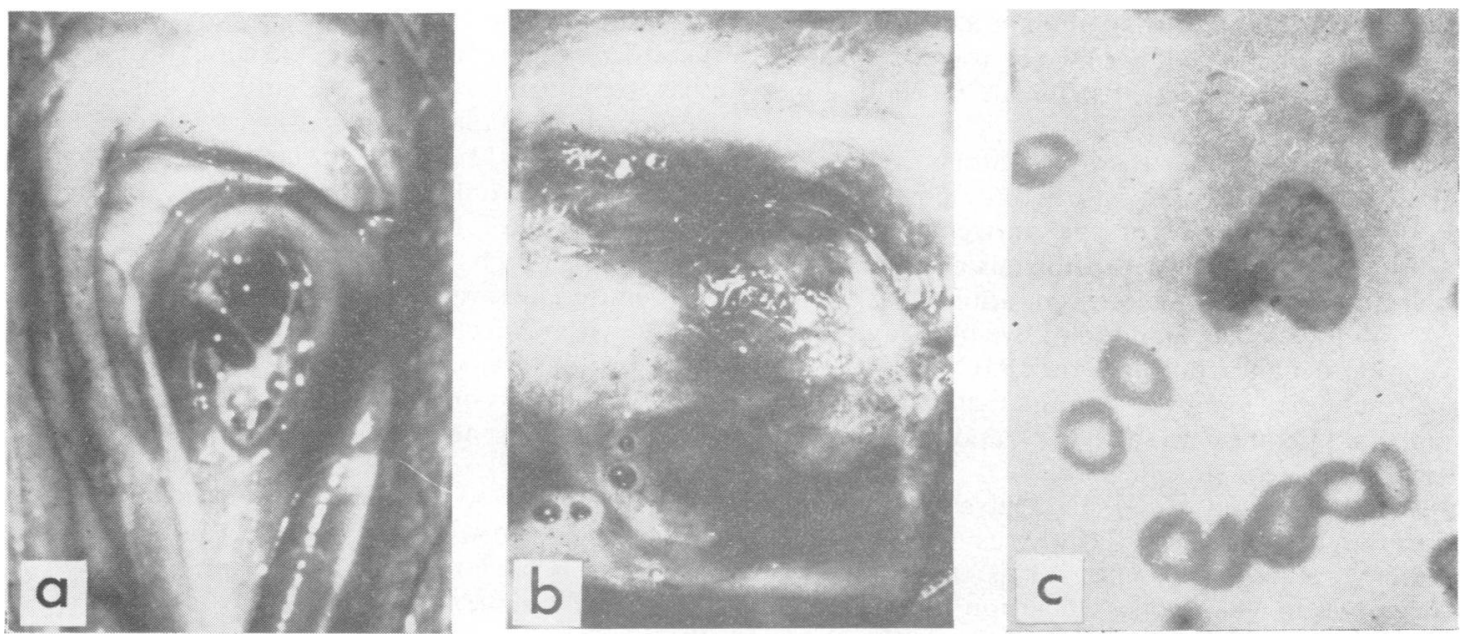

FIG. 17.-TRIC VIRUS INFECTION OF THE GENITAL TRACT associated with trachoma in the case shown in Figs 4 and 5.

(a) Inflamed pouting urethral orifice with muco-purulent discharge.

(b) Cervix, showing granular appearance resembling follicles around external os.

(c) Halberstaedter-Prowazek inclusion body found in scraping from granular area of cervix. Giemsa $\times 1,000$. 
external os bore a remarkable resemblance to the follicles in the conjunctiva. In scrapings of this area I found a typical Halberstaedter-Prowazek inclusion (Fig. 17c). If a baby were to be infected during passage through this cervix, it appeared possible that the ensuing ophthalmic condition would be called inclusion blennorrhoea if the patient lived in England, or trachoma if the patient lived in Egypt.

To put these ideas to the test, Dr. Collier and I inoculated the eye of an adult volunteer with virus isolated from the eye of a baby whose neonatal inclusion blennorrhoea had resolved spontaneously without scarring or pannus. The inoculation was followed by the development of unequivocal trachoma in each eye. It was thus established that one virus (isolate LB4, redesignated TRIC/ /GB/MRC-4/ON) of genital origin, which caused only the self-limiting benign inclusion blennorrhoea syndrome in the neonatal eye, could cause trachoma in the adult eye. Mitsui, Konishi, Nishimura, Kajima, Tamura, and Endo (1962) have recently confirmed this observation.

In view of these findings, it became necessary to give a new name to isolates of virus from the eye and genital tract of patients suffering from either trachoma or inclusion blennorrhoea. This is especially important for the naming of isolates from the genital tract, as it is clear that, at present, only human inoculation experiments can decide whether a given isolate can produce trachoma or only inclusion conjunctivitis. At the VIII International Congress of Microbiology in Montreal in 1963, it was agreed to use "TRIC virus", or more correctly "TRIC agent", as the name for all such isolates, to be followed by various symbols indicating the type and origin of the isolate (TR for trachoma and IC for inclusion conjunctivitis) (Gear, Gordon, Jones, and Bell, 1963).

Considered from the laboratory standpoint, TRIC virus isolates fall into two (or possibly more) groups on the basis of the antigenicity of their mouse-lethal toxin, and possibly also on the basis of their antigenicity for fluorescent antibody.

From the clinical standpoint, we may say that the common ocular syndromes of TRIC virus infection are trachoma, inclusion conjunctivitis, TRIC virus punctate kerato-conjunctivitis, and TRIC virus ophthalmia neonatorum.

Infection of the genital tract gives rise to TRIC virus urethritis and TRIC virus cervicitis, and possibly other syndromes. This terminology is preferable to the names inclusion urethritis and inclusion cervicitis which imply that the genital infections are always the genital counterpart of inclusion conjunctivitis, whereas some, at least, are genital infections with trachoma-producing agents.
Future work will determine what relation the clinical syndromes bear to the immunological or other laboratory subdivisions of TRIC virus isolates.

The full genital importance of all this remains to to assessed, but I believe that the painstaking application, to the study of genital disease, of the methods we have used in the eye will be very rewarding. We can recognize a TRIC virus infection of the eye by its clinical signs and can differentiate it from the conjunctivitis of Reiter's disease. We can, with varying difficulty, prove the aetiology of the eye disease by laboratory investigations. So, I expect that a clinical differential diagnosis of TRIC virus infections of the genital tract will become possible and hope that their laboratory diagnosis will eventually become a routine matter. I suspect that TRIC virus infection may then be shown to be one of the commonest of all sexually-acquired infections and may emerge as a major cause of non-gonococcal urethritis.

\section{Summary}

The clinical features and historical background of trachoma, neonatal inclusion blennorrhoea, and inclusion conjunctivitis of the adult are set out and illustrated. Inclusion conjunctivitis is here divided into stages comparable with the recognized stages of trachoma. This facilitates its understanding and differential diagnosis. When 47 cases of inclusionpositive ocular TRIC virus infection were reviewed, it was seen that there was a spectrum of clinical pictures ranging from typical trachoma to typical inclusion conjunctivitis, with a group of cases of the syndrome newly-described as "TRIC virus punctate keratoconjunctivitis" lying in between. This suggested that some strains of TRIC virus of high ocular pathogenicity capable of causing trachoma might infect the genital tract in addition to the less virulent strains causing only inclusion conjunctivitis already known to infect the eye from genital sources. A remarkably high rate of exposure to sexuallytransmitted disease was found in the cases of ocular TRIC virus infection of all types. Genital TRIC virus infection was found in association with cases of both inclusion conjunctivitis and trachoma. Virus isolated from neonatal inclusion blennorrhoea caused typical trachoma on inoculation into a volunteer's eye. It is therefore preferable to refer to the neonatal disease as TRIC virus ophthalmia neonatorum and to refer to the genital disease as TRIC virus cervicitis or TRIC virus urethritis, since the pathogenicity for the human eye of any isolate from the genital tract can, at present, be determined only by experimental human inoculation.

It is suggested that, when the detailed methods of 
clinical and laboratory examination used in the study of TRIC virus infections of the eye are applied to the elucidation of so-called "non-specific" genital infection, it may be found possible to recognize genital TRIC virus infections by their clinical features, and that these agents may be shown to account for a considerable proportion of sexually-transmitted disease.

I am indebted to my colleagues for their kindness in referring cases for investigation; to Mr. Peter Watson for his help in the clinical and cytological investigations; $\mathrm{Mr}$. Derek Betts and Mr. J. Robinson for their help in finding inclusions; to the Department of Medical Illustration for the illustrations. Dr. L. H. Collier, Honorary Director, Medical Research Council Trachoma Research Unit, Lister Institute of Preventive Medicine, carried out the isolations of virus and many of the ideas embodied in this paper were evolved in collaboration with him.

\section{REFERENCES}

Collier, L. H., Duke-Elder, S., and Jones, B. R. (1958). Brit. J. Ophthal., 42, 705. and Sowd, J. (1958). Lancet, 1, 993.

Fritsch, H., Hofstätter, A., and Lindner, K. (1910). v. Graefes Arch. Ophthal., 76, 547.

Gear, J. H. S., Gordon, F. B., Jones, B. R., and Bell, S. D. (1963). Nature (Lond.), 197, 26.

Halberstaedter, L., and Prowazek, S. von (1907). Arb. Gesundh.-Amte (Berl.), 26, 44.

- (1910). Berl. klin. Wschr., 47, 661.

Hanna, L., Zichosch, J., Jawetz, E., Vaughan, D. G., and Thygeson P. (1960). Science, 132, 1660.

Jones, B. R. (1961). Trans. ophthal. Soc. U.K., 81, 367.

-, Collier, L. H., and Smith, C. H. (1959). Lancet, $1,902$.

Lindner, K. (1909a). Z. Augenheilk., 22, 547.

- (1909b). Wien. klin. Wschr., 22, 1697; 1742.

(1910a). Ibid., 23, 283.

(1910b). v. Graefes Arch. Ophthal., 76, 559.

Mitsui, Y., Konishi, K., Nishimura, A., Kaiima, M., Tamura, O., and Endo, K. (1962). Brit. J. Ophthal., 46, 651 .

Rice, C. E. (1936). Amer. J. Ophthal., 19, 1.

Stargardt, K. (1909). v. Graefes Arch. Ophthal., 69, 525.

T'ang, F.-F., Chang, H.-L., Huang, Y.-T., and Wang, K. C. (1957). Chin. med. J., 75, 429.

Thygeson, P. (1938). Amer. J. Pathol., 14, 455.

(1962). Ann. N.Y. Acad. Sci., 98, 6; 201.

WHO (1962). Tech. Rep. Ser. No. 234. WHO Expert Committee on Trachoma, 3rd Report.

\section{DISCUSSION}

Dr. A. Grimble (Guy's Hospital, London) thanked Prof. Barrie Jones for his most stimulating paper. He had been interested to hear that he could recognize a smear taken from the urethra as being a "trachoma type" smear zven although inclusions were not present. With regard to the inclusions-were they always circumscribed crescents or did they ever appear in the form of elements scattered throughout the cytoplasm of the affected cell? Was it zertain that follicular conjunctivitis was always recognizable and could it be distinguished always from the zonjunctivitis occurring in Reiter's disease? Conjunctivitis quite frequently occurred in patients suffering from nonspecific urethritis and the unskilled observer found it difficult to say whether this conjunctivitis was roughened and follicular or allergic in type.

DR. W. Fo'vler (General Hospital, Birmingham) was particularly interested as he was engaged in writing up 15 years' work on "sago grain" urethritis, a condition in which the urethral mucosa shows changes somewhat similar to those of trachoma. According to Frei an antigen made frem a discharge frem sago grain urethritis produces a skin reaction in patients suffering from lymphogranuloma venereum. Ross had reported two cases in Liverpool. Urethral pus from one of the cases was introduced intracerebrally into two mice, one of which died. In about 9 per cent. of cases there were what appeared to be inclusion bodies. He had been unable to repeat Frei's work with antigen from patients suffering from urethritis. Workers in France had reported positive results using an antigen prepared from the urine of patients suffering from "sago grain" urethritis. Because of the lack of response to treatment shown by these patients he took specimens for testing for antibodies to the L.G.V.-trachoma group and the results were negative. What were the results of this test in patients with inclusion urethritis and cervicitis?

DR. R. R. Willcox (St. Mary's Hospital, London) asked if he was correct in understanding that the viruses of trachoma, inclusion blennorrhoea, and of inclusion cervicitis had been cultured, but that virus had not been cultured from cases of non-specific urethritis. If this was true had Prof. Jones any explanation for it? Inclusion bodies in non-specific urethritis had been studied by venereologists for many years and the "tie-up" outlined by Prof. Jones appeared to be the logical one, but the essential link was still lacking.

Prof. Jones had said that trachoma was cured with sulphonamides. Did this apply also to inclusion blennorrhoea? Sulphonamides alone were not particularly successful in the treatment of non-specific urethritis as a whole, and he wondered if there was any difference in the response of these infections.

Prof. Jones had said that trachoma was once common in Europe. Dr. Willcox could remember having seen these cases as a student, and it might be asked whether this change had come about because treatment cut short some of these infections.

Mr. A. J. KING (Whitechapel Clinic, London) said that Prof. Jones' findings were very interesting. He was not sure whether he had been describing a new venereal disease or whether he had found the "break-through" they had all been hoping for in this difficult subject. Like Dr. Fowler, he had been impressed with the resemblance between some of the appearances in trachoma and the urethroscopic picture of "sago grain" urethritis. If he understood correctly, evidence of virus infection in the genital tracts of women who had borne infants with inclusion blennorrhoea had been found by Prof. Jones, but he had not had the same success in men. These differences were characteristic of the venereal diseases; 
for instance, $T$. vaginalis was easy to find in women and difficult to find in men, while the gonococcus was often easy to find in men and difficult to find in women. Perhaps the same thing applied in this case.

What they wanted to see in the future was a wide application of this investigation in cases of non-specific urethritis quite apart from its relation to infection of the eye. He supposed the logical thing was to start investigating the problem in women, and he had no doubt that Prof. Jones and Dr. Dunlop would have this very much in mind. Dr. Willcox had put his finger on the point that didn't quite add up — why were sulphonamides so effective in the treatment of the eye infection while they were relatively ineffective in the treatment of "non-specific" genital infections? He hoped that Prof. Jones would continue with his fascinating work and solve many of these problems.

Dr. ERIC Dunlop (Whitechapel Clinic, London) asked about the differentiation between these ocular syndromes. Cases had been recorded in which a syndrome other than trachoma had left a little residual scarring.

DR. R. D. CatTerall (General Infirmary, Leeds) asked for details of the techniques used for examining the conjunctival and urethral scrapings and whether there was any serological test which might be of use in diagnosis.

DR. G. Csonka (St. Mary's Hospital, London) asked if non-specific urethritis was particularly common in areas with a high incidence of trachoma.

Dr. R. S. Morton (Royal Hospital, Sheffield) asked whether the $\mathrm{pH}$ of the conjunctival sac was known. He understood that the application of cortisone to the conjunctiva in trachoma resulted in an enormous increase of inclusions. Would this method be useful in the urethra? Was trachoma a relapsing disease? In non-specific urethritis about 10 per cent. of cases relapsed within about 5 years. What was the response of trachoma to treatment with modern anti-viral drugs such as I.C.I. 17025 which were successful in about 40 to 50 per cent. of cases of non-specific urethritis.

DR. F. Lydon (King's College Hospital, London) said that the speakers had solved a problem for him. He had found that, in a proportion of cases of non-specific urethritis, small basophil bodies could be seen in urethral smears; probably some of these were due to inclusion blennorrhoea but most cases of non-specific urethritis were not. In most cases of non-specific urethritis, sulphonamides were ineffective, no organism could be found, and the disease could be associated with what used to be called "gonorrhoeal rheumatism". He had never heard of inclusion blennorrhoea causing arthritic symptoms.

DR. J. J. Rohatiner (Guy's Hospital, London) referred to the slides showing trachoma produced experimentally in a human volunteer. Such volunteers would hardly be forthcoming in V.D. departments, and he wondered if they would be necessary in view of the present success in finding the organism in the laboratory.

Prof. Barrie Jones thanked the audience for the formidable list of questions which were even more searching than the ones which usually came from an audience of ophthalmologists! Dr. Grimble had asked about cytology; one could only make the diagnosis of TRIC virus infection if one found the typical inclusions. If numerous "toxic" epithelial cells were present, with a mixed inflammatory response of polymorphonuclear leucocytes and round cells, this was the picture seen in TRIC virus infection and that infection could be the cause. The appearances of the inclusions varied within certain limits. The typical ones were the crescents, which had been shown. Occasionally the elementary bodies were scattered with the odd particle not adjacent to the others. These particles were of uniform size, within a definite range, and were grouped. In genital scrapings he had often seen particles scattered over a whole cell as described by Dr. Grimble; he thought these particles tended to be somewhat larger than TRIC virus particles and they were eosinophilic with Giemsa stain; these were probably keratin granules. He did not think the diagnosis could be made without finding a grouped body of uniformlystaining particles. Halberstaedter and von Prowazek had called these bodies Chlamydozoa because they appeared to exist within a mantle or inside a vacuole in the cell cytoplasm. Description is difficult but with practice it soon becomes possible to say whether a structure is, or is not, a virus inclusion.

He did not know if it would be possible always to distinguish TRIC virus conjunctivitis from the conjunctivitis of Reiter's disease, but he suspected that this was so. Many ophthalmologists did not recognize TRIC virus conjunctivitis, and much depended upon how enthusiastically the disease was studied. In his experience the conjunctivitis of Reiter's disease was a short-lived hyperaemia associated with some diffuse infiltration and oedema. It was not follicular and it resolved in 2 or 3 weeks or less, whereas TRIC virus conjunctivitis persisted for months. Scrapings from the conjunctiva in Reiter's conjunctivitis showed normal epithelial cells and the exudate was of unmixed polymorphs. Arthritis and uveitis did not occur in trachoma. He agreed with the speakers who had made the point that TRIC virus probably accounted for only a proportion of cases of non-specific urethritis.

Dr. Fowler had quoted the work of Ross who had used urethral material as antigen for a Frei test.

The antigens of virus grown in the yolk sac and isolated from the cervix, from the eye of neonates, and from the eye in trachoma could serve as antigens for the Frei test. Virus grown in the yolk sac could be quantitated by complement-fixation; the use of urethral material for antigen was uncertain. He suspected that the variable results obtained with urethral material were due to variation in the amount of antigen present. In TRIC virus infection the Frei test gave variable results.

With regard to the complement-fixation test: the volunteers who had been infected experimentally developed a rising titre to $1: 16$ or 32 which then declined. Sera from patients with trachoma gave variable results which should be related to the stage of the disease; Trachoma 1V was, of course, a residual finding which could be likened to a calcified scar found in the lung on 
chest $x$ ray. It seemed that a small rise in complementfixing antibodies could occur in inclusion blennorrhoea, but this required further study. Patients with genital and ocular infection appeared to have a higher titre than those with eye disease alone.

Dr. Fowler and others had mentioned the question of treatment with sulphonamides. In his own experience, sulphonamides were always effective in TRIC virus infection of the eye when given in full systemic dose, as were tetracyclines which, when applied locally, were less effective than systemic sulphonamides. Studies had shown that these preparations had a specific effect upon the growth of TRIC virus in eggs.

When TRIC virus infection of the eye was cured by treatment, although the patient might say that the eye felt better, it might take 2 to 4 weeks before there was any definite clinical change.

Dr. Willcox had asked about the cultivation of TRIC virus from trachoma. Virus has been grown from the cervix of the mother of a baby with inclusion blennorrhoea in a West African village where every baby born is being studied by Dr. Collier's team; four babies have been born with infection and virus has been grown from the cervix of the mother in two cases. One of these mothers had twins: one twin died, but the other lived 9 months and in that time developed pannus, which shows that it had trachoma so that the virus in the mother's cervix was presumably a trachoma-producing virus. No one had yet published an account of growing TRIC virus from the male urethra, but Dr. Dunlop, Dr. Hussaini, and he hoped to do so very soon. They had obtained an isolate which was in its tenth yolk-sac passage. This account was of work since 1959. Mr. King's point that the virus was difficult to grow from the male urethra was valid but it was only slightly less difficult to grow it from the cervix; The yolk-sac method was not very sensitive.

The personnel of the Harvard University and Aramco Trachoma Project in Saudi Arabia had shown that in general, in primitive villages, 80 per cent. of the children had trachoma, scrapings showed inclusions in about 40 per cent of all children. In a less primitive village, 60 per cent. might be infected, and inclusions might be found in perhaps 10 per cent. This might be compared with the findings in the children of employees of the local oil companies; 50 per cent. of them might have trachoma and there was a 1 per cent. incidence of inclusions. TRIC virus had to be in the eye a long time to produce serious disease, and merely washing the face was evidently an effective form of treatment. Thus, in the more advanced villages, one saw only "trachoma under treatment", and these eyes contained less virus than those in the primitive villages. The virus was only grown when there were a large number of inclusions.

Regarding Dr. Dunlop's point about the ocular syndromes, he considered that the term trachoma should be reserved for a clinical syndrome. If the patient had an infection of the eye caused by any member of this group and developed scarring, then the eye syndrome should be termed trachoma.

Dr. Catterall had asked about the technique for taking scrapings; the most important point was to recognize the disease clinically. If ten cases of non-specific urethritis were examined, it was possible that say only one due to TRIC virus infection would be found. That is why, at that stage, it was felt that it would be worth starting with patients who had the infection in their eyes or whose babies had it in their eyes. Scrapings should be taken from the site of maximal disease. A light scrape was required and the smears should be fixed in methyl alcohol and stained with Giemsa. Every cell on each slide should be scrutinized but that was so time-consuming that it could not be regarded as a satisfactory routine method. New diagnostic methods would be forthcoming but were not yet available. Serological tests might show complement-fixation to the lymphogranuloma-venereumTRIC group of viruses, but did not indicate whether the patient had TRIC virus infection.

Dr. Fowler had mentioned the mouse which died after cerebral inoculation. If controls were satisfactory this would be prima facie evidence of lymphogranulomavenereum infection, as TRIC virus did not grow in mouse brain on primary isolation. The question of defining the field of lymphogranuloma-venereum virus infection was going to become much more difficult and was very important when virus was isolated from the genital tract. The virus which had been isolated from the urethra did not affect the eyes of guinea-pigs, mice, and rabbits. It was not, he thought, a lymphogranuloma-venereum virus.

Dr. Csonka's question whether non-specific urethritis was common in areas with a high incidence of trachoma was difficult to answer; in Arab and Moslem countries women could not readily be examined and men resented genital inspection as a slur upon their manhood, but there was said to be a high incidence of genital discharges. There were some interesting analogies between syphilis, gonorrhoea, and TRIC virus infection. In undeveloped countries in tropical areas syphilis could be a non-venereal disease, but in more civilized countries it was purely a sexually-transmitted infection. In Egypt, gonorrhoea could be transmitted as an epidemic eye-toeye disease, but in areas free from Muscus aleus, the eyeseeking fly, the disease was always transmitted sexually.

With regard to treatment he had no knowledge of compound I.C.I. 17025 unless this was the one which had been used in trachoma by Prof. Beattie with disappointing results.

In reply to Dr. Rohatiner's question about inoculation of human volunteers: apes could be infected but the cornea was not involved and the disease differed from that produced in man. It was necessary to prove that the agent which had been isolated was the cause of trachoma and for this reason the inoculation of human volunteers had been necessary. The only reason for such experiments would be to evaluate the pathogenicity to the human eye of an isolate and this was clearly something which would require to be done in only a few instances.

Les manifestations oculaires du virus TRIC et leur
importance génitale RÉSUMÉ

L'auteur décrit les symptômes et l'histoire du trachome, 
de la blennorragie à inclusions chez le nouveau-né, et de la conjonctivite à inclusions chez l'adulte.

Comme le trachome, la conjonctivite à inclusions est divisée en trois stades, ce qui facilite le diagnostic.

Une revue de 47 cas d'infection oculaire par le virus TRIC à inclusions montre toute une gamme de tableaux cliniques, du trachome typique à la conjonctivite à inclusions, en passant par un syndrome que l'on nomme "kérato-conjonctivite ponctuée due au virus TRIC". Ceci fit croire que quelques souches du virus TRIC capables de causer le trachome pouvaient infecter les organes génitaux, tandis que l'origine génitale des souches moins virulentes qui ne causent que la conjonctivite est déjà connue.

Les malades atteints d'infection oculaire de tout genre due au virus TRIC constatèrent avoir très souvent risqué l'infection sexuelle. On trouva l'infection génitale due au virus TRIC dans les cas de blennorragie à inclusions et dans ceux de trachome.

L'inoculation d'un virus isolé d'un nouveau-né atteint de blennorragie à inclusions dans l'oeil d'un témoin volontaire causa le trachome classique.

Il est donc préférable de nommer la lésion du nouveauné "ophtalmie néonatale due au virus TRIC" et de nommer la lésion génitale "cervicite ou urétrite due au virus TRIC", puisque l'effet sur l'oeil humain de n'importe quelle souche isolée des organes génitaux ne peut être déterminé que par l'inoculation expérimentale dans l'oeil humain.

Quand les méthodes exactes déjà employées dans la recherche du virus TRIC oculaire seront appliquées à l'étude des infections urétrales dites "non-spécifiques", on espère pouvoir reconnaître les virus TRIC génitaux par leurs caractères cliniques; on pourra alors découvrir si ces virus sont la cause de plusieurs des maladies non-spécifiques vénériennes ou non. 